Article - Agriculture, Agribusiness and Biotechnology

\title{
Unveiling Xylanolytic Enzymes Production of Talaromyces wortmannii DR49 on Industrial Agro Wastes
}

\author{
Diogo Robl ${ }^{1 *}$ \\ https://orcid.org/0000-0002-2959-176X
}

\author{
Vania Vicente ${ }^{2}$ \\ https://orcid.org/0000-0002-2953-4861
}

Ida Chapaval Pimentel ${ }^{2}$

https://orcid.org/0000-0002-1840-1748

\section{Gabriel Padilla ${ }^{3}$}

https://orcid.org/0000-0001-8086-3065

\section{José Geraldo da Cruz Pradella \\ https://orcid.org/0000-0002-2902-0983}

\begin{abstract}
${ }^{1}$ Federal University of Santa Catarina (UFSC), Department of Microbiology, Immunology and Parasitology, Florianópolis, Brazil; ${ }^{2}$ Federal University of Paraná (UFPR), Department of Basic Pathology, Curitiba, Brazil; ${ }^{3}$ University of São Paulo (USP), Department of Microbiology, São Paulo, Brazil; ${ }^{4}$ Federal University of Sao Paulo (UNIFESP), Department of Science and Technology, São José dos Campos, São Paulo, Brazil.
\end{abstract}

Editor-in-Chief: Alexandre Rasi Aoki

Associate Editor: Ana Cláudia Barana

Received: 2020.11.10; Accepted: 2021.06.02.

*Corresponding author: diogo.robl@ufsc.br; Tel.: +55-48-3721 7159 (D.R.).

\section{HIGHLIGHTS}

- Process development to produce xylanolytic enzymes by Talaromyces wortmannii.

- First report of T. wortmannii cultivation in bioreactors using industrial agro wastes.

- The best condition for xylanolytic enzymes production were $29^{\circ} \mathrm{C}$ and $\mathrm{pH} 6.0$.

Abstract: Xylan degradation is an important step in different industries, such as in biorefinery for biomass hydrolysis. Talaromyces wortmannii is a known fungus due to second metabolite production but only few works showed the xylanolytic potential of this fungus. In this way, the aim of this study was to evaluate the production of xylanolytic enzymes from T. wortmannii DR49 on industrial agro wastes. Cultivation in shake flask showed highest xylanase titration $(10.3 \mathrm{U} / \mathrm{mL} ; 9.5 \mathrm{U} / \mathrm{mL})$ for wheat bran (WB) and hydrothermal pretreated sugar cane bagasse (HB); in $\beta$-xylosidase production WB and xylose were the best carbon sources $(0.57 \mathrm{U} / \mathrm{mL} ; 0.34 \mathrm{U} / \mathrm{mL})$ respectively. STR cultivation revealed that $29^{\circ} \mathrm{C}$ and $\mathrm{pH} 6.0$ were the best conditions for xylanase $(14.5 \mathrm{U} / \mathrm{mL})$ and $\beta$-xylosidase $(1.7 \mathrm{U} / \mathrm{mL})$ production. T. wortmannii DR49 showed to be a potential candidate for xylanolytic enzymes production using agro wastes in bioreactors, which has never been previously reported in this fungus. 
Keywords: Talaromyces wortmannii; xylanase; $\beta$-xylosidase; agro wastes; sugar cane bagasse.

\section{INTRODUCTION}

Xylan degradation can be an important step in different industry products, such as breadmaking and in biorefinery [1]. Several studies showed that enzymatic plant biomass deconstruction can be improved by the enzymatic hemicellulose removal that lead for higher cellulose hydrolysis yields [2-4]. Xylan degradation is mainly performed by endo 1,4- $\beta$-xylanases (EC 3.2.1.8) that cleaves glycosidic bonds in the xylan backbone and $\beta$-xylosidase (EC 3.2.1.37) that acts in the hydrolysis of xylobiose and larger xylooligosaccharides release [1]. It is important to highlight that xylanolytic enzymes can also be applied to xylan recovery from lignocellulosic biomass and contribute to biomass valorization. One high value-added that can be obtained is xylooligosaccharides (XOS), these oligomers are considered non-digestible carbohydrates that present prebiotic effect [5].

Lignocellulosic biomass substrates have been extensively applied in glycohydrolases production by filamentous fungi with the objective of media cost reduction. Pretreated sugar cane bagasse, wheat straw, cotton seed hulls, soybean hulls had been used in media formulation to xylanolytic enzymes production by several ascomycetes species [2, 6, 7].

Talaromyces genera contains species with medical, industrial and agriculture importance. It was firstly describe as a sexual state of Penicillium, and further was redefined by polyphasic taxonomy approach $[8,9]$. Some species present biotechnological potential due to enzyme production, such as Talaromyces cellulolyticus for cellulase [10] and Talaromyces emersonii for xylanase [11]. Furthermore, Talaromyces spp can produce xylanolytic enzymes with desires biochemical characteristics. Wang and coauthors [12] identified in Talaromyces leycettanus JCM 12802 highly thermostable xylanase able to hydrolyze wheat straw. Nieto-Domínguez and coauthors [13] produced and purified a pH-stable $\beta$-xylosidase from Talaromyces amestolkiae with regioselective transxylosylation activity.

Talaromyces wortmannii belongs to section Islandici which is a group easily recognized by its slow or restricted growth and conspicuous yellow aerial mycelium [14]. In one hand T. wortmannii is a known fungal species due to the production of second metabolites with biological activities [15]. Some examples are wortmannilactones, that presented cytotoxic activity against some human cancer cell lines [16]; skyrin and rugulosin A, that presented antibiotic activity against some Gram positive pathogenic bacteria [17]. In the other hand, few works showed glycohydrolase production by this fungus. The first report of xylanolytic enzymes production by $T$. wortmannii was made by Lee and coauthors [18], which screened xylanolytic Penicillium spp isolated from woods materials. Further Robl and coauthors [19] showed that a strain isolated from spoiled books, T. wortmannii DR49, produces a wide profile of several hemicellulases capable to hydrolases plant cell wall and that its enzymatic production is mainly related to media carbon source.

It is important to highlight that xylanolytic enzymes of section Islandici species is unexplored and that $T$. wortmannii glicohydrolases may present biochemical and catalytic characteristics potential to industrial application. Antonopoulou and coauthors [20] produced by heterologous expression and tested three feruloyl esterases from $T$. wortmannii with ability for the transesterification and syntheses of feruloyl derivatives. In this way, this study aimed to evaluated xylanolytic enzymes production by T. wortmannii DR49 on plant biomass materials and study the influence of temperature and $\mathrm{pH}$ parameters in bioreactor fungus cultivation.

\section{MATERIAL AND METHODS}

\section{Fungal strain}

T. wortmannii DR49 is an ascomycete isolated from spoiled books and screened as a potential xylanolytic producer [19]. The strain was kindly given by the fungal collection of the Laboratório de Microbiologia e Biologia Molecular of Universidade Federal do Paraná (LabMicro/UFPR). The microorganism was stored in cryotubes with glycerol $20 \%$ at $-80^{\circ} \mathrm{C}$.

\section{Lignocellulose materials}

It was tested five industrial agro waste rich in cellulose and hemicellulose: Hydrothermal pre-treatment of sugarcane bagasse (HB), steam-exploded sugar cane bagasse (EB), steam-exploded delignified sugar cane bagasse (DEB), liquor, soybean bran (SB) and wheat bran (WB). EB and DEB were prepared and characterized by Rocha and coauthors [21] and dos Santos Costa and coauthors [7] and sugar cane bagasse was provided from Rosário Mill (Orlândia, Brazil). Hydrothermal pre-treatment of sugarcane bagasse was 
performed previously by Robl and coauthors [22] to produce the solid (HB) and liquid fractions (Liquor) used in this study. Both materials had chemical composition determined also by Robl and coauthors [22]. Other lignocellulose materials such as SB and WB were provided from Agricola (São Carlos, Brazil) [23]. The material composition is presented at tables S1 and S2 (Supplementary material).

\section{Culture media}

The culture medium [24], originally applied to cellulase production, was adapted according to Robl and coauthors [19] and used in this study: $1 \mathrm{~mL}$ Tween 80; $0.3 \mathrm{~g} / \mathrm{L}$ urea; $2.0 \mathrm{~g} / \mathrm{L} \mathrm{KH}_{2} \mathrm{PO}_{4} ; 1.4 \mathrm{~g} / \mathrm{L}\left(\mathrm{NH}_{4}\right)_{2} \mathrm{SO}_{4} ; 0.4$ $\mathrm{g} / \mathrm{L} \mathrm{CaCl} 2.2 \mathrm{H}_{2} \mathrm{O} ; 0.3 \mathrm{~g} / \mathrm{L} \mathrm{MgSO}_{4} .7 \mathrm{H}_{2} \mathrm{O} ; 1.0 \mathrm{~g} / \mathrm{L}$ proteose peptone; $5.0 \mathrm{mg} / \mathrm{L} \mathrm{FeSO}$.7H2O; $1.6 \mathrm{mg} / \mathrm{L}$ $\mathrm{MnSO}_{4} .4 \mathrm{H}_{2} \mathrm{O} ; 1.4 \mathrm{mg} / \mathrm{L} \mathrm{ZnSO} 4.7 \mathrm{H}_{2} \mathrm{O} ; 2.0 \mathrm{mg} / \mathrm{L} \mathrm{CoCl} 2.6 \mathrm{H}_{2} \mathrm{O} ; 10 \mathrm{~g} / \mathrm{L}$ glucose (carbon source). The medium $\mathrm{pH}$ was settled to 5.0 and then sterilized $\left(121^{\circ} \mathrm{C}\right.$ for $\left.20 \mathrm{~min}\right)$. All the culture medium used present identical composition, with exception of carbon sources, which varied among assays.

\section{Shake flask cultures}

Fungal conidia were harvested by the addition of sterilized Tween $80(0.01 \% \mathrm{v} / \mathrm{v})$ on $T$. wortmannii colonies ( $7^{\text {th }}$ day growth on potato dextrose agar, PDA). Erlenmeyer flasks $(500 \mathrm{~mL})$ with $200 \mathrm{~mL}$ of culture medium with glucose $(10 \mathrm{~g} / \mathrm{L})$ was inoculated with $T$. wortmannii conidia $\left(3 \times 10^{6}\right.$ conidia $/ \mathrm{mL}$ of medium) and incubated for $48 \mathrm{~h}$ at $29^{\circ} \mathrm{C}$ at $200 \mathrm{rpm}$. This pre-culture $(20 \mathrm{~mL})$ was transferred to $500 \mathrm{~mL}$ Erlenmeyer flasks containing $180 \mathrm{~mL}$ of the production medium and cultivated at $29^{\circ} \mathrm{C}$ at $200 \mathrm{rpm}$ for $144 \mathrm{~h}$. This assay was performed in triplicates.

\section{Stirred tank reactor cultivation}

Based on the results obtained in shake flask assays and based on ascomycetes bioreactor cultivations [2,22], stirred tank reactor (STR) batches were conducted using 3.0-L BioFlo® 115 bioreactors (New Brunswick Scientific Co.) with $1.0 \mathrm{~L}$ working volume to evaluate the kinetics of enzyme production. The $\mathrm{pH}$ was controlled with the addition of $0.4 \mathrm{M} \mathrm{H}_{2} \mathrm{SO}_{4}$ or $1: 3(\mathrm{v} / \mathrm{v}) \mathrm{NH}_{4} \mathrm{OH}: \mathrm{H}_{2} \mathrm{O}$ and the temperature was kept at $29^{\circ} \mathrm{C}$. Stirring and aeration varied respectively $(200-500 \mathrm{rpm} ; 0.3-1.0 \mathrm{~L} / \mathrm{min})$ to maintain dissolved oxygen level above $30 \%$ of air saturation. The medium was inoculated with fungi cells $10 \%(\mathrm{v} / \mathrm{v})$ from the shaken flask pre-culture as described in the item above. Polyglycol antifoaming (FluentCane 114, DOW Chemical, Brazil) was added manually if required. Samples were periodically collected, cells were removed by centrifugation $\left(10,000 \times \mathrm{g}, 10^{\circ} \mathrm{C}\right.$ for $\left.15 \mathrm{~min}\right)$ and supernatants were used for enzymatic activities assays.

\section{Carbon source, temperature and $\mathrm{pH}$ influence in enzyme production}

Evaluation of xylanolytic enzymes production under industrial agro-industrial were accessed in shake flask cultures at $29^{\circ} \mathrm{C}$ at $200 \mathrm{rpm}$ for $144 \mathrm{~h}$. Six lignocellulose materials and one sugar were evaluated at 10 g/L: HB, EB, DEB, SB, WB, liquor and xylose. Then two carbon sources with promising results were used with higher dry matter $(20 \mathrm{~g} / \mathrm{L}$ for each carbon source) for shake flask cultures (200 rpm for $144 \mathrm{~h})$ at $29^{\circ} 32^{\circ}$ and $35^{\circ} \mathrm{C}$. The $\mathrm{pH}$ influence was performed in STR cultivations at $\mathrm{pH} 4.0,5.0$ and 6.0 to access enzymatic production under a pH controlled process (Duplicates only for $\mathrm{pH}$ 5.0). In bioreactor assays, temperature and carbon source were selected based on the highest results obtained previously in shaken flask cultivation.

\section{Analytical methods}

Xylanolytic activity was determined as xylanase and $\beta$-xylosidase titration. Xylanase activity was determined employing Beechwood xylan $(0.5 \% \mathrm{w} / \mathrm{v})$ and DNS method for reducing sugars quantification (xylose as standard). The reactions were carried out at pH 5.0 with $90 \mu \mathrm{L}$ of $50 \mathrm{mM}$ citrate buffer and $10 \mu \mathrm{L}$ diluted centrifugation supernatant [19]. $\beta$-xylosidase activity was measured using $10 \mu \mathrm{L}$ of sample and 90 $\mu \mathrm{L}$ of the 4-nitrophenyl $\beta$-D-xylopyranoside (Sigma-Aldrich, USA) at $0.5 \mathrm{mM}$, diluted in $50 \mathrm{mM}$ citrate buffer at $\mathrm{pH}$ 5.0. The reactions were incubated for $10 \mathrm{~min}$ at $50^{\circ} \mathrm{C}$ and enzymatic hydrolysis were interrupted by $100 \mu \mathrm{L}$ of DNS or $1 \mathrm{M} \mathrm{Na}_{2} \mathrm{CO}_{3}$ for xylanase and $\beta$-xylosidase respectively [19]. The absorbances were measured by the micro plate reader Tecan Infinite ${ }^{\circledR} 200$ (Switzerland) at $400 \mathrm{~nm}$ ( $\beta$-xylosidase) and $540 \mathrm{~nm}$ (xylanase). One unit of glycohydrolases activity (in International Units, $U$ ) corresponds to $1 \mu \mathrm{mol}$ of xylose or pNP released per minute. 


\section{Statistical analysis}

Enzymatic activities produced at $29^{\circ} 32^{\circ}$ and $35^{\circ} \mathrm{C}$ were evaluated by analysis of variance (ANOVA), means were compared by Tukey test at $1 \%$ with Statistica 10.0 software (Statsoft, Inc., Tulsa, OK, USA).

\section{RESULTS AND DISCUSSION}

To evaluate the influence of different carbon sources on xylanolytic enzymes by $T$. wortmannii DR49 shake flask cultivation were performed. It was tested six carbon sources rich in cellulose and hemicellulose (HB, EB and DEB), hemicellulose (SB and WB), xylooligomers (Liquor) and pure xylose at $1 \%(\mathrm{w} / \mathrm{v})$, material composition is presented at tables S1 and S2 (Supplementary material). Figure 1 shows the xylanase and $\beta$ xylosidase activities as a time course over $144 \mathrm{~h}$ of cultivation.
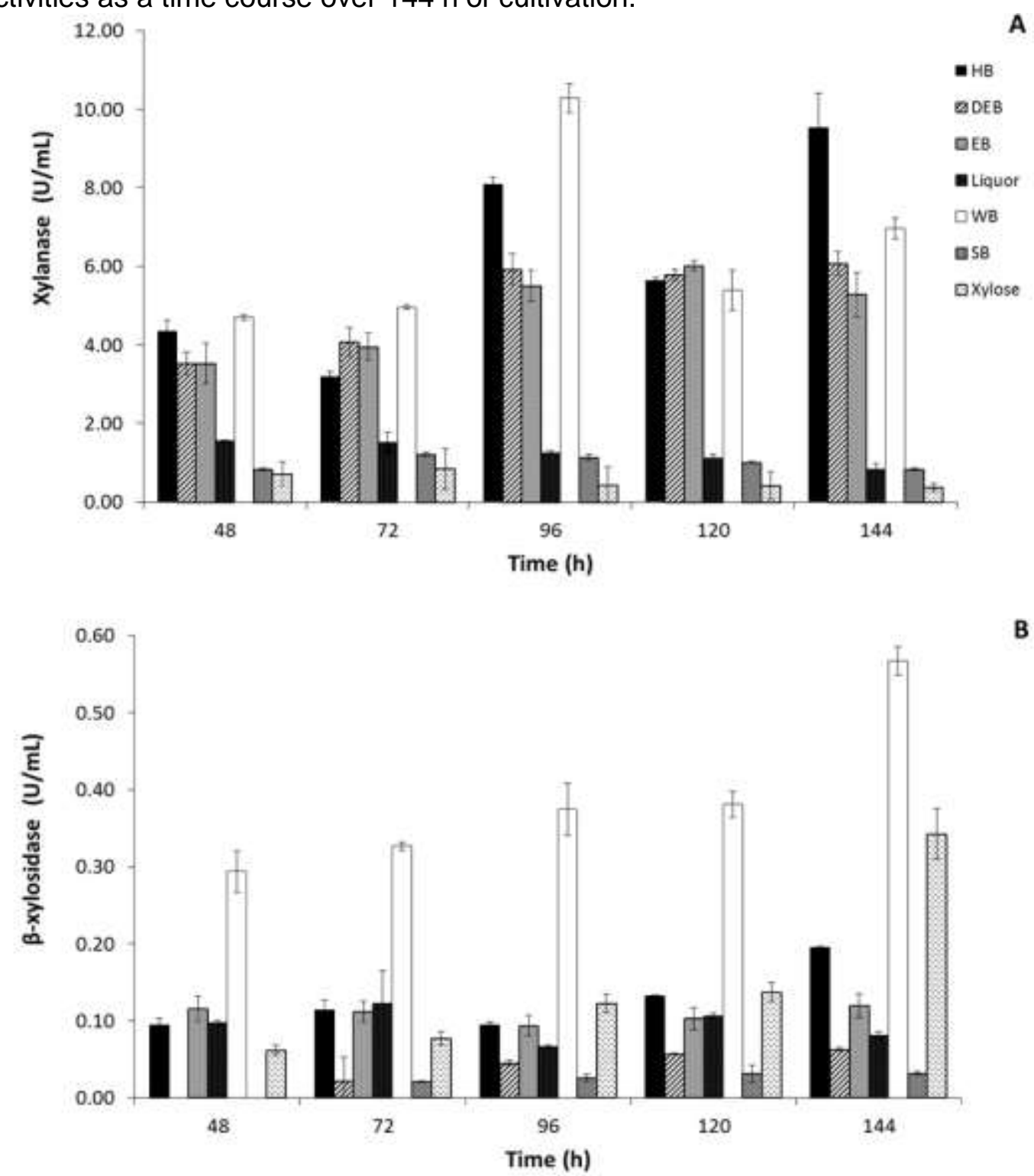

Figure 1. Influence of different carbon sources on xylanase $(A)$ and $\beta$-xylosidase (B) production by Talaromyces wortmanii DR49 in shake flask cultivation.

Evaluation of xylanase production under industrial agro-industrial wastes showed that the highest enzyme concentration was obtained on materials rich in hemicellulose. The best results obtained were for WB $(10.3 \mathrm{U} / \mathrm{mL})$ at $96 \mathrm{~h}$ and $\mathrm{HB}(9.5 \mathrm{U} / \mathrm{mL})$ at $144 \mathrm{~h}$. WB has been used in others works to induce xylanolytic enzymes due to high proportions of arabinoxylan [25]. Romdhane and coauthors [26] produced xylanase and $\beta$-xylosidase by Talaromyces thermophiles in WB shaken flask cultivation and obtained enzymatic activities approximately of $4.5 \mathrm{U} / \mathrm{mL}$ and $1.5 \mathrm{U} / \mathrm{mL}$ respectively. According to Robl and coauthors [22] HB presented the following composition: cellulose $(56.03 \%)$, hemicellulose $(4.59 \%)$, lignin $(36.36 \%)$ ashes $(4.24 \%)$. Despite of the fact that HB presented high percentage of lignin which may hamper fungal growth and 
enzymatic production, the presence of hemicellulose induced xylanase production. The same results were observed by Robl and coauthors [2], in which xylanase production by Aspergillus niger was higher in HB instead of EB and DEB.

In $\beta$-xylosidase production the highest titration observed were for WB $(0.57 \mathrm{U} / \mathrm{mL})$ and xylose $(0.34$ $\mathrm{U} / \mathrm{mL}$ ) at $144 \mathrm{~h}$. Xylose was not able to induce xylanase production, although this saccharide seems to play a role in $\beta$-xylosidase production. Llanos and coauthors [27] studied the influence of carbon source in the transcriptional levels of glicohydrolase genes in Talaromyces versatilis and verified that xylose did not induce dose-dependent inhibitory effect for xylanases and $\beta$-xylosidase synthesis.

Xylose cost can makes unfeasible its use for industrial enzyme production. In this way, liquor from hydrothermal sugar cane pretreatment which is rich in xylose and xylooligomers was tested. Although liquor presented xylose $(4.7 \pm 0.41 \mathrm{~g} / \mathrm{L})$ and xylooligomers $(9.98 \pm 1.13 \mathrm{~g} / \mathrm{L})$, low xylanases and $\beta$-xylosidase activities were obtained (Figure 1). This result corroborates with Robl and coauthors [2], according to the authors xylanolytic batch enzyme production by $A$. niger DR02 was negatively impacted by liquor xylose concentration. In this way, a fedbatch cultivation was developed to keep xylose concentration at low levels. Consequently it reduced CCR effect and increased xylanolytic enzymes production. Besides liquor contain inhibitors (Table S1) that can affect negatively enzyme production such as lignin $(3.15 \mathrm{~g} / \mathrm{L})$, furfural $(1.05 \mathrm{~g} / \mathrm{L})$ and hydroxymethylfurfural $(0.18 \mathrm{~g} / \mathrm{L})$. In ascomycetes fungi SB has been extensively used in glycohydrolase production such as $\beta$-glucosidase, pectinase and xylanase $[7,22]$. However in our work this agro waste was not able to induce none of the measured enzymes activities. Even though SB is composed by $18.13 \%$ of hemicellulose, the high amount of protein is presented (43.22\%) [23]. This fact could induce proteases production and also increase media $\mathrm{pH}$ due to protein metabolism.

As presented in figure $1 \mathrm{WB}$ and $\mathrm{HB}$ were best the carbon source to produce both enzymes. In this way, the fungus was grown in both carbon source in higher concentration, $\mathrm{HB}(20 \mathrm{~g} / \mathrm{L})$ and WB $(20 \mathrm{~g} / \mathrm{L})$ to evaluate the influence of temperature and $\mathrm{pH}$ in xylanolytic enzymes production. Previous works with ascomycetes showed that higher polysaccharides concentration could lead to higher glycohydrolase production [7, 22]. Robl and coauthors [22] showed that pectinase and $\beta$-glucosidase production by Annulohypoxylon stygium were higher when citrus bagasse and SB concentration were increased and use simultaneously $(20 \mathrm{~g} / \mathrm{L}$ for each carbon source).

It was investigated the xylanolytic production under three different temperatures $\left(29,32\right.$ and $\left.35^{\circ} \mathrm{C}\right)$. Samples were collected at 96, 120 and $144 \mathrm{~h}$, once that the production peak occurs during this period (Figure 1). T. wortmannii DR49 was able to growth and produced xylanase and $\beta$-xylosidase activities under the three conditions tested (Table 1). The highest enzymatic activity obtained for both enzymes were at $29^{\circ} \mathrm{C}$ at $144 \mathrm{~h}$ and differed from higher temperatures by Tukey test $(p<0.01)$. A drastically decrease in enzyme production was observed at $35^{\circ} \mathrm{C}$ for both enzymes. According to Yilmaz and coauthors [14] T. wortmannii is able to growth poorly at $37^{\circ} \mathrm{C}$, but is not able to growth at $40^{\circ} \mathrm{C}$ in Czapek Yeast Autolysate Agar (CYA).

The $\mathrm{pH}$ is also a parameter that impacts directly glycohydrolases production. Due to fungal metabolism, during cultivation, $\mathrm{pH}$ fluctuation occurs on non $\mathrm{pH}$ controlling medium. In order to minimize that, bioreactor cultivations at $\mathrm{pH} 4.0,5.0$ and 6.0 were performed to evaluate the kinetics of enzyme production in a controlled batch environment (Figure 2).

Xylanase and $\beta$-xylosidase presented similar production profiles in batch bioreactor for each different $\mathrm{pH}$. The highest xylanase titration was obtained for $\mathrm{pH} 6.0$ with production peaked at $120 \mathrm{~h}(14.5 \mathrm{U} / \mathrm{mL})$ (Figure 2A). Regarding to $\beta$-xylosidase, $\mathrm{pH} 6.0$ and 5.0 showed similar results in enzyme production with the highest enzymatic activity $(1.7 \mathrm{U} / \mathrm{mL}$ and $1.5 \mathrm{U} / \mathrm{mL}$ ) at 144 respectively (Figure $2 \mathrm{~B})$. These data indicates that acid $\mathrm{pH}$, values above 5.0, can influence negatively in xylanolytic enzymes production. In ascomycetes $\mathrm{pH}$ plays a role in xylanolytic enzymes production. The $\mathrm{pH}$ can affect the expression of some Aspergillus genes encoding glycohydrolases [28]. According to MacCabe and coauthors [29] Aspergillus nidulans xylanase genes $(x \ln A$ and $x \operatorname{In} B)$ are $\mathrm{pH}$ regulated via $\mathrm{PacC}$ factor and depending on media $\mathrm{pH}$ one is expressed instated another.

Members of Talaromyces genera produce various glycohydrolases including cellulases and hemicellulases [30], although only few works reported the enzymatic production of Talaromyces section Islandici. The only studies of xylanlolytc enzymes production of $T$. wortmannii are from Lee and coauthors [18] and Robl and coauthors [19], although none of them verified the influence of $\mathrm{pH}$, temperature and agro wastes on fungal enzyme production. Lee and coauthors [18] obtained high $\beta$-xylosidase titration by $T$. wortmannii cultivation at $25^{\circ} \mathrm{C}$ in pure substrates, such as beechwood xylan $(3.82 \mathrm{U} / \mathrm{mL})$ and birchwood xylan $(2.17 \mathrm{U} / \mathrm{mL})$. Similar result was obtained by Robl and coauthors [19], that cultivated T. wortmannii DR49 in beechwood xylan at $\mathrm{pH} 5.0$ and $29^{\circ} \mathrm{C}$ and produced $\beta$-xylosidase activity $(2.85 \mathrm{U} / \mathrm{mL})$. Regarding to xylanase 
activity our work, showed that it was possible to increase this enzymatic titration in $240 \%$ when compared to Robl and coauthors [19] that used pure xylan for xylanase production $(6.00 \mathrm{U} / \mathrm{mL})$.
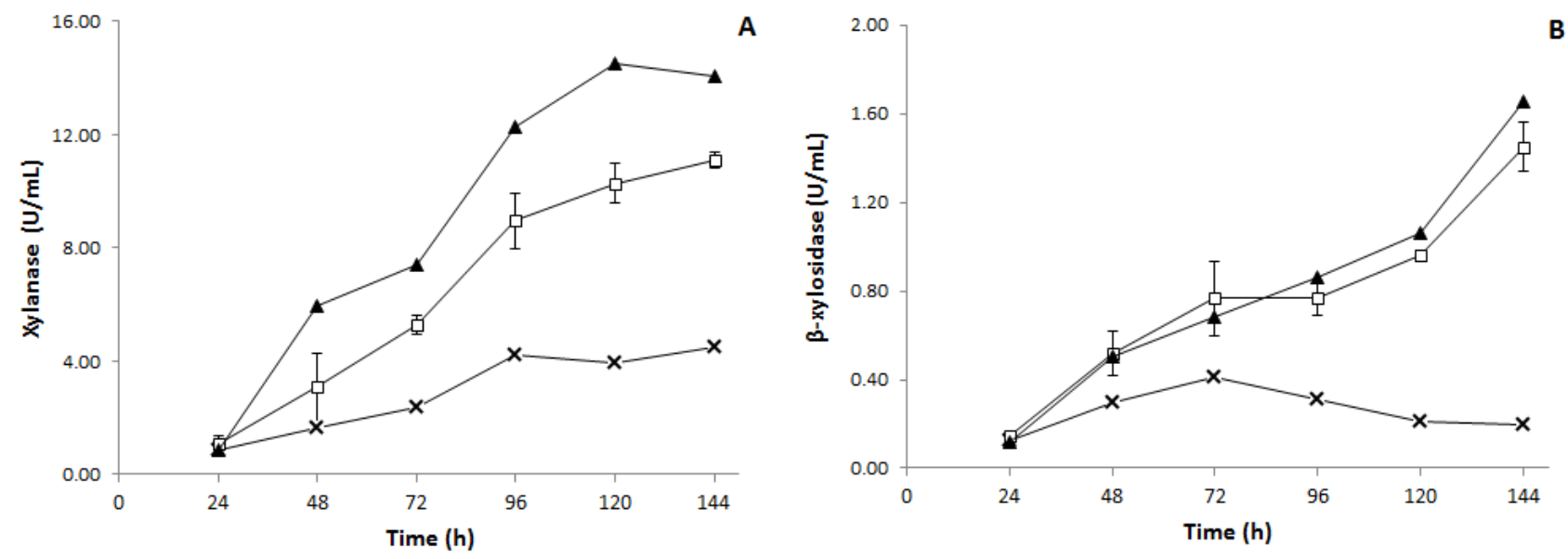

Figure 2. Xylanase (A) and $\beta$-xylosidase (B) activities of Talaromyces wortmannii DR49 cultivation on STR in $\mathrm{pH} 4.0$ $(\mathrm{X}), \mathrm{pH} 5.0(\square)$ and $\mathrm{pH} 6.0(\mathbf{\Delta})$ at $29^{\circ} \mathrm{C}$.

\section{CONCLUSION}

T. wortmanii DR49 showed to be a potential candidate for xylanolytic enzymes production using plant biomass materials in bioreactors, which has never been previously reported in this fungus. Submerged cultivation revealed that the best temperature and $\mathrm{pH}$ for xylanase and $\beta$-xylosidase production are $29^{\circ} \mathrm{C}$ and 6.0. Biochemical characterization of $T$. wortmanii DR49 xylanase and $\beta$-xylosidase, as well as a culture media optimization must be performed to verify xylanolytic enzyme applicability.

Funding: This research was funded by Fundação de Amparo à Pesquisa do Estado de São Paulo (FAPESP) and Conselho Nacional de Desenvolvimento Científico e Tecnológico (CNPq), Grant number 2011/10834-0 and 140154/2011-6.

Acknowledgments: We gratefully acknowledge the Brazilian Biorenewables National Laboratory (LNBR/CNPEM)for the facilities.

Conflicts of Interest: The authors declare no conflict of interest. The funders had no role in the design of the study; in the collection, analyses, or interpretation of data; in the writing of the manuscript, or in the decision to publish the results.

\section{REFERENCES}

1. Harris AD, Ramalingam C. Xylanases and its application in food industry: a review. J Exp Sci. 2010, 1(7).

2. Robl D, da Silva Delabona P, dos Santos Costa P, da Silva Lima DJ, Rabelo SC, Pimentel IC, et al. Xylanase production by endophytic Aspergillus niger using pentose-rich hydrothermal liquor from sugarcane bagasse. Biocatal Biotransformation. 2015, 33(3):175-87.

3. Berlin A, Maximenko V, Gilkes N, Saddler J. Optimization of enzyme complexes for lignocellulose hydrolysis. Biotechnol Bioeng. 2007, 97(2):287-96.

4. Gottschalk LMF, Oliveira RA, da Silva Bon EP. Cellulases, xylanases, $\beta$-glucosidase and ferulic acid esterase produced by Trichoderma and Aspergillus act synergistically in the hydrolysis of sugarcane bagasse. Biochem Eng J. 2010;51(1-2):72-8.

5. lenczak JL, Poletto P, Robl D, Rabelo SC. Transforming the Lignocellulosic Biomass into High Value-Added Bioproducts. Bio-valorization of Waste: Trends and Perspectives. 2021:21-51.

6. Mäkelä MR, Bouzid O, Robl D, Post H, Peng M, Heck A, et al. Cultivation of Podospora anserina on soybean hulls results in an efficient enzyme cocktail for plant biomass hydrolysis. New biotechno. 2017;37:162-71.

7. dos Santos Costa P, Buchli F, Robl D, Delabona Pda S, Rabelo SC, Pradella JG. Enhancement of Penicillium echinulatum glycoside hydrolase enzyme complex. J Ind Microbiol Biotechnol. 2016 May;43(5):627-39.

8. Yilmaz N, Visagie CM, Houbraken J, Frisvad JC, Samson RA. Polyphasic taxonomy of the genus Talaromyces. Stud Mycol 2014;78:175-341.

9. Samson R, Yilmaz N, Houbraken J, Spierenburg H, Seifert K, Peterson S, et al. Phylogeny and nomenclature of the genus Talaromyces and taxa accommodated in Penicillium subgenus Biverticillium. Stud Mycol 2011;70:159-83. 
10. Inoue H, Decker SR, Taylor LE, Yano S, Sawayama S. Identification and characterization of core cellulolytic enzymes from Talaromyces cellulolyticus (formerly Acremonium cellulolyticus) critical for hydrolysis of lignocellulosic biomass. Biotechnol biofuels. 2014;7(1):151.

11. Tuohy MG, Coughlan MP. Production of thermostable xylan-degrading enzymes by Talaromyces emersonii. Bioresour Technol. 1992;39(2):131-7.

12. Wang $\mathrm{X}$, Huang $\mathrm{H}$, Xie $\mathrm{X}$, Ma $\mathrm{R}$, Bai $\mathrm{Y}$, Zheng $\mathrm{F}$, et al. Improvement of the catalytic performance of a hyperthermostable GH10 xylanase from Talaromyces leycettanus JCM12802. Bioresour Technol. 2016;222:27784.

13. Nieto-Domínguez M, de Eugenio LI, Barriuso J, Prieto A, de Toro BF, Canales-Mayordomo Á, et al. Novel pH-stable glycoside hydrolase family $3 \beta$-xylosidase from Talaromyces amestolkiae: an enzyme displaying regioselective transxylosylation. Appl Environ Microbiol. 2015;81(18):6380-92.

14. Yilmaz N, Visagie C, Frisvad JC, Houbraken J, Jacobs K, Samson R. Taxonomic re-evaluation of species in Talaromyces section Islandici, using a polyphasic approach. Persoonia: Molecular Phylogeny and Evolution of Fungi. 2016;36:37.

15. Zhai M-M, Li J, Jiang C-X, Shi Y-P, Di D-L, Crews $P$, et al. The bioactive secondary metabolites from Talaromyces species. Nat prod bioprospect. 2016;6(1):1-24.

16. Dong Y, Yang J, Zhang H, Lin J, Ren X, Liu M, et al. Wortmannilactones A- D, 22-Membered Triene Macrolides from Talaromyces wortmannii. J nat prod. 2006;69(1):128-30.

17. Bara R, Aly AH, Pretsch A, Wray V, Wang B, Proksch $\mathrm{P}$, et al. Antibiotically active metabolites from Talaromyces wortmannii, an endophyte of Aloe vera. J antibiot. 2013;66(8):491-3.

18. Lee J, Jang Y, Lee H, Lee S, Kim G-H, Kim J-J. Screening for xylanase and $\beta$-xylosidase production from woodinhabiting Penicillium strains for potential use in biotechnological applications. Holzforschung. 2012;66(2):267-71.

19. Robl D, Delabona Pda S, Mergel CM, Rojas JD, Costa Pdos S, Pimentel IC, et al. The capability of endophytic fungi for production of hemicellulases and related enzymes. BMC biotechnol. 2013;13:94.

20. Antonopoulou I, lancu L, Jütten P, Piechot A, Rova U, Christakopoulos P. Screening of novel feruloyl esterases from Talaromyces wortmannii for the development of efficient and sustainable syntheses of feruloyl derivatives. Enzyme microb technol. 2019;120:124-35.

21. Rocha GJM, Goncalves AR, Oliveira BR, Olivares EG, Rossell CEV. Steam explosion pretreatment reproduction and alkaline delignification reactions performed on a pilot scale with sugarcane bagasse for bioethanol production. Ind Crops Prod. 2012 Jan;35(1):274-9.

22. Robl D, dos Santos Costa P, Büchli F, da Silva Lima DJ, da Silva Delabona P, Squina FM, et al. Enhancing of sugar cane bagasse hydrolysis by Annulohypoxylon stygium glycohydrolases. Bioresour technol. 2015;177:247-54.

23. Rodriguez-Zuniga UF, Farinas CS, Neto VB, Couri S, Crestana S. Aspergillus niger production of cellulases by solid-state fermentation. Pesquisa Agropecuaria Brasileira. 2011 Aug;46(8):912-9.

24. Mandels M, Reese ET. Induction of cellulase in fungi by cellobiose. J Bacteriol. 1960 1960;79(6):816-26.

25. Beaugrand J, Crônier D, Debeire P, Chabbert B. Arabinoxylan and hydroxycinnamate content of wheat bran in relation to endoxylanase susceptibility. J Cereal Sci. 2004;40(3):223-30.

26. Romdhane IBB, Achouri IM, Belghith H. Improvement of highly thermostable xylanases production by Talaromyces thermophilus for the agro-industrials residue hydrolysis. Appl biochem biotechnol. 2010;162(6):1635-46.

27. Llanos A, Déjean S, Neugnot-Roux V, François JM, Parrou J-L. Carbon sources and XInR-dependent transcriptional landscape of CAZymes in the industrial fungus Talaromyces versatilis: when exception seems to be the rule. Microb cell fact. 2019;18(1):14.

28. de Vries R. Regulation of Aspergillus genes encoding plant cell wall polysaccharide-degrading enzymes; relevance for industrial production. Appl microbiol biotechnol. 2003;61(1):10-20.

29. MacCabe A, Orejas M, Perez-Gonzalez J, Ramón D. Opposite Patterns of Expression of Two Aspergillus nidulans Xylanase Genes with Respect to Ambient pH. J bacteriol. 1998;180(5):1331-3.

30. Fujii $\mathrm{T}$, Hoshino $\mathrm{T}$, Inoue $\mathrm{H}$, Yano $\mathrm{S}$. Taxonomic revision of the cellulose-degrading fungus Acremonium cellulolyticus nomen nudum to Talaromyces based on phylogenetic analysis. FEMS microbiol letters. 2014;351(1):32-41. conditions of the Creative Commons Attribution (CC BY NC) license (https://creativecommons.org/licenses/by-nc/4.0/). 